Derecho \& Realidad

Núm. 24 • II semestre de 2014

Facultad de Derecho y Ciencias Sociales, UPTC

ISSN: 1692-3936

\title{
Jtinerario de la crisis humanitaria en Siria
}

\author{
Javier Henao Hidrón
}

Antes de surgir la crisis social y política que concita estos comentarios, Siria era un país de 21 millones de habitantes y $185.180 \mathrm{~km}^{2}$, situado en la región del Cercano Oriente, limítrofe con Turquía, el Mar Mediterráneo, Líbano, Israel, Jordania e Irak.

La llamada primavera árabe empezó en Siria en marzo de 2011 con un movimiento de protesta contra la dictadura de los Asad (el general Hafiz, el padre, gobernó con mano de hierro durante veintinueve años y Bashar, el hijo, lleva doce en la misma línea). La actitud del gobierno fue todavía más cruel que en Libia, pues reaccionó sin imponerse límites contra los rebeldes y sus eventuales apoyos dentro de la población civil, mientras Rusia ${ }^{1}$ y China le brindaban apoyo e impedían con su veto que el Consejo de Seguridad de las Naciones Unidas aprobara un plan de la Liga Árabe para una transición a la democracia, así como propuestas destinadas a presionar y sancionar a un desprestigiado régimen que abiertamente vulneraba los derechos humanos.

$\mathrm{Al}$ cumplirse el primer año, el total de muertos llegaba a 10.000, correspondiendo unos 7.200 a la ciudad opositora de Homs; 25.000 personas habían huido de Siria y 70.000 se habían desplazado dentro del país. El comisario de paz de la ONU, Kofi Annan, no encontró eco en un gobierno que prefería atacar a su propio pueblo, al tiempo que el presidente Obama denunciaba "un atroz baño de sangre". Con

\footnotetext{
El Tiempo, en editorial, explicaba: "Siria no solo es un aliado político de Moscú, sino un excelente cliente desde los tiempos en que existían el Kremlin y el dictador padre. Las armas que dispara el ejército de Al Asad contra los rebeldes provienen de Rusia (...) Más que proteger la estabilidad política siria, Moscú protege contratos de armas por 4.000 millones de dólares. Como gran concesión, Vladimir Putin dijo que no firmará nuevas ventas mientras dure la guerra (...) Estas y otras armas son motivo de preocupación, pues Siria cuenta con el mayor depósito de armas químicas del Oriente Medio" (21-07-12, debes leer, p.18).
} 
todo, los instrumentos jurídicos internacionales se mostraban incapaces de derribar al gobierno y de abrir camino a las legítimas aspiraciones de la población siria.

En el enfrentamiento entre el gobierno y los rebeldes, el hecho más grave reivindicado por el Ejército Sirio Libre, ESL, formado por civiles y militares desertores que se unieron a la insurrección, ocurrió en Damasco el martes 17 de julio de 2012 cuando un guardaespaldas al servicio del gobierno en ataque suicida activó un cinturón de explosivos en el edificio de la Seguridad Nacional y causó la muerte del ministro y el viceministro de Defensa y del jefe de la lucha contra la rebelión, mientras resultaban heridos el ministro del Interior y el jefe de la Seguridad Nacional; este último falleció dos días después. Según el Observatorio Sirio para los Derechos Humanos, OSDH, con sede en Londres, el día de los hechos hubo 121 muertos, distribuidos en 52 soldados, 48 civiles, 18 rebeldes y los tres altos funcionarios. Pocos días después, la Secretaria de Estado de los Estados Unidos, Hillary Clinton, manifestaba que su país estaba trabajando al margen de la ONU para mandar un mensaje claro de apoyo a la oposición y, además, que continuaría no solamente enviando ayuda humanitaria sino presionado al régimen sirio.

Tres semanas más tarde, el enviado especial Kofi Annan presentaba renuncia, dado que ni el gobierno sirio ni los rebeldes cumplieron su plan de paz, al tiempo que responsabilizaba a los miembros del Consejo de Seguridad de no haber actuado unidos para poner fin a un conflicto que "deja más de 17.000 muertos".

Fue cuando la ONU resolvió retirar sus observadores de Siria y reducir su presencia a una oficina política en Damasco; no obstante, nombró como nuevo comisionado al excanciller argelino Lakhdar Brahimi, quien, al tomar posesión, se mostró pesimista, diciendo que su misión era "casi imposible". El conflicto, entretanto, adoptaba las características de una guerra civil.

El gobierno sirio, aunque se consideraba poderoso, buscó ayuda en su mejor aliado, Irán. Este país admitió públicamente el envío de miembros de la Guardia de la Revolución, un cuerpo militar de élite, si bien con la connotación de que se trata únicamente de "consejeros".

En medio de la represión atroz a los rebeldes -llamados "terroristas" por el gobiernocon bombardeos, tanques y artillería, el Consejo de Cooperación del Golfo, CCG, integrado por Arabia Saudita, Qatar, Bahréin, Kuwait, Emiratos Árabes y Omán, instó a la protección de los civiles, condenó "los asesinatos y las masacres contra el pueblo sirio", advirtió a Irán sobre su injerencia en los asuntos internos de sus países miembros y pidió un traspaso pacífico del poder. 
A principios de septiembre de 2012 los rebeldes encontraron apoyo en el líder yihadista jordano conocido como Abu Sayaf, cuya agrupación está vinculada a Al Qaeda. En entrevista concedida en Amán, dijo que ya tiene “más de 150" de sus miembros en Siria, dispuestos a derrocar al gobierno de Bashar Al Asad, de quien afirmó que era un musulmán alawita que estaba cometiendo un "genocidio" contra la mayoría sunnita -sunní- del país, representantes de la ortodoxia musulmana. Agregó que enviará refuerzos, y dirigiéndose al dictador, "Nuestros combatientes van por ti". Ciertamente, el enfrentamiento era ya ostensible entre la minoría chiita (10\%), detentadora del poder y los sunnitas, que representan entre el 60 y el $70 \%$ de la población.

Un mes después, el conflicto amenazaba con extenderse a Turquía, en cuya frontera se presentaron enfrentamientos entre soldados de los dos países que dejaron muertos, heridos y pérdidas materiales; aunque Damasco ofreció disculpas, el parlamento turco autorizó al gobierno para penetrar en territorio sirio, de ser necesario.

Una pequeña luz de esperanza parecía abrirse en noviembre de 2012 cuando China pidió a las partes en conflicto que dieran pasos efectivos hacia un alto al fuego y solicitó al delegado de la ONU liderar la elección de interlocutores con amplia representación para la formulación de una hoja de ruta que facilitara un cambio político "seguro y estable" en Siria.

Al finalizar el año 2012 la guerra continuaba sin alteraciones. Según la estadística del OSDH, el número de muertos era de 45.000 (unos 70 por día) y el de refugiados -en Irak, Jordania, Líbano, Turquía y Egipto- de 550.000. La ONU advertía que, de no cesar la guerra, para junio de 2013 los refugiados podrían duplicarse.

Cumplidos los dos primeros años del levantamiento popular sirio que degeneró en guerra civil -marzo de 2013- la ONU presentó estas desoladoras estadísticas: 70.000 muertos, 100.000 heridos, 2.000 .000 de desplazados internos y 1.000 .000 de refugiados. Pocas semanas después, el secretario de Estado de los Estados Unidos, John Kerry, manifestaba a la prensa que "este baño de sangre debe cesar" y anunciaba el aumento de la ayuda a los rebeldes sirios de 123 a 250 millones de dólares para "suministro de material defensivo" -vehículos, chalecos antibalas, gafas de visión nocturna, sin incluir armas-; al mismo tiempo explicaba: "Lo que está en juego en Siria no puede ser más claro: el uso de armas químicas, la masacre de la población con misiles balísticos y el recurso de otras armas de destrucción masiva".

A mediados de junio de 2013, el Consejo de Seguridad de los Estados Unidos dijo tener pruebas -suministradas por Francia- en el sentido de que el ejército sirio "ha 
utilizado armas químicas, incluido el gas sarín, múltiples veces en el último año", lo que viola la línea roja que trazó el gobierno estadounidense y obliga a dar más apoyo a la oposición. No obstante, semanas después el secretario de Estado manifestaba: "No hay solución militar. Solo hay una solución política", agregando que una conferencia de paz en Ginebra tiene el respaldo de Estados Unidos, Rusia y el secretario general de la ONU, por lo cual deben hacerse los esfuerzos necesarios para concretarla. (Cuatro meses después, la ONU consiguió que las partes en conflicto aceptaran concurrir a una mesa de diálogo, convocada en dicha ciudad para el 22 de enero del año siguiente, en procura de una "solución pacífica").

El día más crítico hasta entonces, punto de partida de consecuencias imprevisibles, fue el 21 de agosto de 2013. Los rebeldes denunciaron un letal ataque químico con gas tóxico en los suburbios de Damasco, que habría dejado centenares de muertos, entre ellos numerosos niños, mientras dormían. Después los mismos rebeldes calcularon el número de víctimas en unas 1.300, en quienes no quedaron huellas de sangre ni heridas apreciables. El Consejo de Seguridad se reunió de inmediato en Nueva York y confió la investigación a un equipo de inspectores de armas químicas de la ONU, el que viajó dos días después a Damasco, pues era indispensable actuar sobre el terreno y tomar muestras de sangre, de orina y de cabello; inicialmente, el gobierno sirio negó el permiso de entrada al área, pero algunos días después cedió, cuando ya podían haber sido borradas las huellas. Mientras tanto, la prensa mundial divulgaba imágenes conmovedoras. Según un miembro del equipo médico que atendió numerosos afectados, "después de dos horas, los cadáveres se volvieron de color azul y más tarde, totalmente negros (...) Ninguno de los que traté tenía heridas. La mayoría padecía dificultades respiratorias, fuertes dolores de cabeza, náuseas y pérdida de visión" 2 . Transcurrida una semana, una fuente oficial de los Estados Unidos declaraba a la prensa que tomando en cuenta la cantidad de víctimas y sus síntomas, y el análisis de la inteligencia estadounidense, había "muy pocas dudas" de que el régimen sirio usó armas químicas contra civiles. Por su parte, el secretario de Estado catalogaba como "innegable" que el gobierno sirio empleó sustancias neurotóxicas para masacrar a cientos de civiles y que, por tanto, debía pagar las consecuencias; se trata de algo muy serio que estremece la conciencia del mundo -agregó- y desafía cualquier código de moralidad. Poco después se anunció que Estados Unidos, con el apoyo de Francia y de algunos países árabes -la Cámara de los Comunes negó por 285 votos contra 272 la autorización para que Inglaterra participara en la operación militar-, como represalia y sin el aval de la ONU, atacaría por 72 horas con misiles crucero Tomahawk lanzados desde barcos los sitios donde se sospecha que están almacenadas armas químicas; por tanto, el ataque no buscaría cambiar el régimen, sino enviar un fuerte mensaje a quienes

El Tiempo, 25-08-13, debes saber, p. 20. 
usan esa clase de armas, prohibidas por el mundo civilizado. (Entretanto, en Damasco, miles de personas huían hacia el Líbano por temor a los bombardeos, incluyendo familias ricas que apoyan al gobierno).

Estados Unidos, el 30 de agosto, con base en un informe oficial codificado suministró esta estadística: 1.429 muertos, incluidos 426 niños. Pero debilitado ante la falta de apoyo de Inglaterra y la posición neutral de Alemania, España y otros aliados europeos -el único que permanecía firme era Francia-, el presidente Obama al día siguiente, en mensaje al Congreso, decidió solicitar su autorización previa, "aunque creo que tengo la autoridad de decretar esta acción militar" y, como consecuencia, les pidió a los miembros de ambas cámaras "aprobar este voto por nuestra seguridad nacional”. (Casi simultáneamente, el Alto Comisionado de la ONU para los Refugiados, Acnur, daba a conocer estas dramáticas estadísticas: 100.000 muertos, 5.000 .000 de desplazados internos y 2.000.000 de refugiados, estos últimos distribuidos así: en Líbano, 720.000; Jordania, 515.000; Turquía, 460.000; Irak, 168.000 y Egipto, 110.000. "Lo que es terrible -dijo el alto comisionado- es que el primer millón huyó de Siria en dos años. El segundo millón huyó en seis meses”).

Los inspectores de la ONU recopilaron evidencia "clara y convincente" de las muertes provocadas por gas sarín, de alto nivel de toxicidad, que ataca directamente el sistema nervioso central -la dosis letal para un adulto es de medio miligramo-, para lo cual fueron usados "cohetes desde tierra hacia tierra que contenían el agente nervioso sarín". El secretario general de la ONU calificó lo ocurrido de "crimen de guerra” y pidió que los responsables sean llevados ante la justicia.

Estados Unidos logró el respaldo de 33 países a una respuesta "fuerte" a los ataques sirios. Fue cuando Rusia propuso que Siria dejara su arsenal de armas químicas bajo control internacional, habiendo obtenido el apoyo inmediato de Damasco y también de la ONU; Obama se pronunció en el sentido de que el plan de Moscú podría conducir a la entrega del material químico y que este fuese destruido, y al retrasar el voto en el Congreso, aseguró que en caso de fallar la diplomacia, pondrá a funcionar la opción militar. Al cabo de tres días de conversaciones entre los delegados de Estados Unidos y Rusia, en Ginebra, el 14 de septiembre se llegó a un acuerdo: Siria, en un plazo de 7 días, presentará el listado de sus armas químicas; la Organización para la Prohibición de Armas Químicas, $\mathrm{OPAQ}^{3}$, se encargará de supervisar todos los sitios de almacenamiento y la destrucción total así de las armas

\footnotetext{
El mes siguiente, la OPAQ, con sede en La Haya (Holanda), organización encargada de aplicar la Convención contra las Armas Químicas, vigente desde 1997 y suscrita por 190 Estados -Siria adhirió el 14 de octubre de 2013-, fue galardonada con el Premio Nobel de la Paz. El otorgamiento se sustentó en que "se ha verificado la destrucción de 58.172 toneladas de agentes químicos, $81,71 \%$ del arsenal declarado"; concebido, además, como un impulso a la causa de la paz en Siria.
} 
como de la infraestructura para producirlas, operación que deberá estar completa para el 30 de junio de 2014. Este último punto fue puesto en duda por expertos, quienes recordaron que la destrucción de la red de armas químicas en Irak, que era menor, tomó un poco más de tres años; empero, la entrega se completó, para su destrucción en el extranjero, una semana antes de la fecha prevista.

El 21 de enero de 2014, día previo al inicio en Suiza de las conversaciones entre el régimen y los rebeldes, encuentro promovido por la ONU con un triple objetivo: el cese de la violencia, el establecimiento de un órgano de gobierno transitorio y la adopción de medidas para compensar y rehabilitar a las víctimas, un informe de tres exfiscales internacionales ilustrado con numerosas imágenes, denunciaba el asesinato sistemático de unos 11.000 detenidos en las cárceles de guerra gubernamentales. Para entonces, las estadísticas revelaban, además de 21.600 millones de dólares en daños causados en ciudades y monumentos -antiguos y modernos-, 130.000 muertos, 200.000 heridos, 5’300.000 desplazados internos y 2`338.200 refugiados, distribuidos así: en Líbano, 820.900; en Jordania, 582.200; en Turquía, 571.500; en Irak, 212.900; en Egipto, 132.400 y en África del Norte (Marruecos, Argelia, Libia), 18.300. Las conversaciones empezaron en medio del escepticismo recíproco y un mes después, terminaban lánguidamente. El 11 de marzo siguiente, el conflicto cumplía tres años y continuaba sin alteraciones.

Entretanto, se anunciaron elecciones presidenciales para el 3 de junio siguiente, en las cuales Al Asad buscará su reelección; la reglamentación expedida por el Parlamento exige a los candidatos haber vivido en Siria de forma continua durante los últimos diez años y contar con el respaldo de 35 de sus miembros. La oposición las consideró una "farsa" y "parodia de democracia" y en términos similares se expresaron los líderes de los principales países de Occidente, mientras para el secretario general de la ONU "obstaculizan la perspectiva de una solución política". Rusia, en cambio, las calificó de "legítimas". Realizadas en las zonas controladas por el régimen, Bashar obtuvo un tercer mandato de siete años con el 88,7 \% de los votos emitidos por el 73,42 \% de los sufragantes potenciales.

El gravísimo conflicto sirio no ofrece perspectivas de concluir a corto plazo, dado el radicalismo de las partes enfrentadas y la imposibilidad jurídica de las Naciones Unidas de intervenir, por la división en el seno del Consejo de Seguridad.

Cuando llegue el momento de iniciar la reconstrucción del país, el mundo civilizado se encontrará ante una tarea gigantesca. 